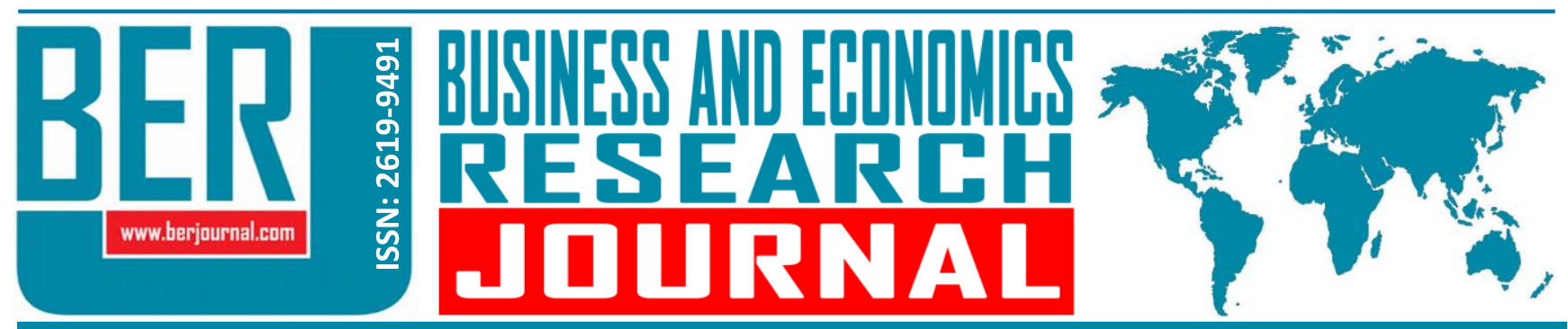

Business and Economics Research Journal Vol. 12, No.3, $2021 \quad$ pp. 557-573

doi: $10.20409 /$ berj.2021.338

\title{
Türk İmalat Sanayinde Rekabet ve Verimlilik İlişkisi: Firma Düzeyinde Bir Analiz
}

\section{Ramazan Ekinci ${ }^{\mathrm{a}}$}

Öz: Bu çalışmanın amacı rekabetin toplam faktör verimliliği (TFP) üzerindeki etkisini 2011-2019 dönemi için imalat sanayinde faaliyet gösteren seçilmiş 77 firma için analiz etmektir. Firmaların rekabet gücü ölçüsü Lerner indeksi kullanılarak hesaplanmaktadır. Toplam faktör verimliliği ise stokastik sınır analizi (SFA) yöntemi kullanılarak maliyet fonksiyonuna dayalı olarak tahmin edilmektedir. Yapılan tahmin sonucunda, toplam faktör verimliliği büyüme oranı 2015 yılından sonra hızlı bir şekilde azalmakta, 2018 ve 2019 yıllarında ise negatif olmaktadır. Firmaların rekabet gücünü gösteren Lerner indeksi ortalaması \%35,06 olarak gerçekleşmiş olmakla birlikte, rekabet düzeyinde önemli bir değişiklik görülmemektedir. Sektörler itibariyle yapılan ayrıştırmada, TFP büyüme hızı en düşük sektör Ana Metal Sanayi iken; en yüksek TFP büyümesine sahip sektör Kimya ilaç Petrol Lastik ve Plastik Ürünleri sektörüdür. Öte yandan, en rekabetçi sektör Kâğıt ve Kâğıt Ürünleri, Basım ve Yayın sektörü iken; en az rekabetin olduğu sektör Taş ve Toprağa Dayalı alt sektördür. Çalışmanın bulguları rekabet ve toplam faktör verimliliği arasındaki ilişkinin doğrusal olmadığı yönündedir. Firmalar için tahmin edilen rekabet (1-Lerner indeks) eşik değeri 0,322'dir. Rekabet eşik değerin altında (yoğunlaşan piyasa) iken rekabet artışının toplam faktör verimliliği üzerindeki etkisi anlamsızdır. Rekabet eşik değerin üzerine (rekabetçi piyasa) çıktığında rekabet artışııı toplam faktör verimliliği üzerindeki etkisi pozitif ve istatistiksel olarak anlamlı olmaktadır.

\section{The Relationship Between Competition and Productivity in the Turkish Manufacturing Industry: A Firm-Level Analysis}

\begin{abstract}
This study aims to analyze the effect of competition on total factor productivity (TFP) for selected 77 companies operating in the manufacturing industry for the 2011-2019 period. The competitiveness of firms is calculated using the Lerner index. Total factor productivity is estimated based on the cost function using the stochastic frontier analysis (SFA) method. As a result of the estimation, the total factor productivity growth rate decreases rapidly after 2015 and becomes negative in 2018 and 2019. Although the average Lerner index, which shows the competitive power of the companies, is $35.06 \%$, there is no significant change in the level of competition. Among the sectors, while the Basic Metal Industry is the lowest sector in terms of TFP growth rate; the sector with the highest TFP growth is the Chemicals, Petroleum Rubber and Plastic Products sector. On the other hand, while the most competitive sector is the Paper and Paper Products, Printing and Publishing, the sector with the least competition is the Non-Metallic Mineral Products Sub-sector. The findings of the study shows that the relationship between competition and total factor productivity is not linear. The estimated competition (1-Lerner index) threshold value for firms is 0.322 . When competition is below the threshold, the effect of increased competition on total factor productivity is insignificant. When competition is above the threshold, the effect of increased competition on total factor productivity is positive and statistically significant.
\end{abstract}

Anahtar Sözcükler: Rekabet, Verimlilik, Imalat Sanayi, Panel Veri Analizi, Stokastik Sınır Analizi

JEL: C24, D22, L11

$\begin{array}{ll}\text { Geliş } & : 22 \text { Mart } 2021 \\ \text { Düzeltme } & : 26 \text { Mayıs } 2021 \\ \text { Kabul } & : 28 \text { Haziran } 2021 \\ \text { Tür } & : \text { Araştırma }\end{array}$

Keywords: Competition, Productivity, Manufacturing Industry, Panel Data Analysis, Stochastic Frontier Analysis

JEL: C24, D22, L11

$\begin{array}{ll}\text { Received } & : 22 \text { March } 2021 \\ \text { Revised } & : 26 \text { May } 2021 \\ \text { Accepted } & : \text { 28 June } 2021 \\ \text { Type } & \text { : Research }\end{array}$
Cite this article as: Ekinci, R. (2021). Türk imalat sanayinde rekabet ve verimlilik ilişkisi: Firma düzeyinde bir analiz. Business and Economics Research Journal, 12(3), 557-573. http://dx.doi.org/10.20409/berj.2021.338

The current issue and archive of this Journal is available at: www.berjournal.com

a Asst. Prof., PhD., Izmir Bakircay University, Faculty of Economics and Administrative Sciences, Department of Economics, Izmir, Turkiye, ramazan.ekinci@bakircay.edu.tr (ORCID ID: 0000-0001-7420-9841) 


\section{Giriş}

Firmaların verimlilik düzeylerinin en iyi durumunu açıklamak amacıyla yapılan çalışmalar genelde iki temel teorik yaklaşıma dayanarak analiz edilmektedir. Bunlardan ilki, yapı-davranış-performans (structureconduct-performance; SCP) paradigmasına dayanan endüstriyel organizasyon (industrial organization; 10 ) teorisidir. Bu yaklaşımda piyasa yoğunlaşması, giriş engelleri ve endüstri yaşam döngüsü gibi endüstriye özgü faktörlere bağlı olarak endüstriyel yapının firma verimliliği üzerindeki etkisi araştırılmaktadır (Caloghirou, Protogerou, Spanos ve Papagiannakis, 2004). İkinci yaklaşım ise, verimlilikteki bir iyileşmenin firmaya özgü sahip olduğu yeteneklerinden kaynaklandığını ileri süren kaynak-temelli teoridir. Burada, rekabet ettikleri endüstriye bakılmaksızın verimlilik farklılıklarını belirleyen temel faktörün, firmaların kullanabileceği kaynakların heterojenliğine bağı olduğu kabul edilmektedir. SCP paradigmasına göre, firmanın en iyi verimlilik düzeyi, fiyatlandırma politikası, AR-GE, yatırım politikası ve reklam kararı gibi firma davranışlarıyla belirlenmektedir. Burada, daha yüksek verimliliğe yol açan piyasa rekabeti hipotezi, teorik literatürün ortaya koyduğu karşılık sonuçlar nedeniyle, daha çok ekonometrik teknikler kullanılarak tahmin edilmektedir (Kato, 2009). Ürün piyasası rekabeti yoğunlaşması, şirket yöneticileri üzerinde daha rekabetçi baskılar oluşturmasıyla onları, firmaların verimliliğini artırmak için daha fazla çaba göstermeye zorlamaktadır (Nickell, 1996). Türkiye özelinde, piyasa rekabeti ile verimlilik arasındaki ilişkiyi araştıran uygulamalı çalışmaların sayısı oldukça azdır. Bundan dolayı mikro iktisat politikaların uygulanmasına yönelik yararlanılacak bulgu miktarı da azdır. Bu nedenle, bu çalışma kısmen de olsa literatürdeki bu boşluğu gidermeye çalışmaktadır.

Yapı-davranış-performans (SCP) paradigmasının belirttiği gibi, piyasa rekabetinin veya yoğunlaşmasının derecesi ve giriş engellerinin seviyesi gibi piyasa yapılarının, piyasaların ekonomik performansını etkilediği varsayılmaktadır. Giriş maliyetlerindeki bir azalma gibi daha etkin düzenlemelere yol açan reformlar, sektörler içinde ve sektörler arasında firmalar arasında rekabeti artırması beklenmektedir. Rekabetteki bu artışın, mevcut kaynakları düşük verimlilik düzeyine sahip firmalardan daha yüksek verimlik düzeyine sahip firmalara doğru yeniden tahsisini sağlaması beklenmektedir (Poschke, 2009). Bununla birlikte, içsel büyüme ile ilgili literatür, rekabet ve verimlilik konusunda zıt görüşler ortaya atmaktadır. Standart içsel teknolojik değişim (Romer, 1986; Aghion ve Howitt, 1992) modeline göre, ürün piyasası rekabetindeki bir artışın, yeniliklerden beklenen gelecekteki kârları ve dolayısıyla teknik değişim oranını azaltması beklenmektedir (rant dağıtımı etkisi). Bununla beraber, daha yoğun rekabetin, yeniliklerin beklenen sürekliliğini (yaratıcı yıkım) ve dolayısıyla yeniliği yaratma özendirici etkisini azaltacağı öngörülmektedir.

Özellikle piyasalardaki rekabet düzeyi başta olmak üzere, verimlilik veya büyümedeki farklılıkların hangi tür endüstriyel piyasa yapısı tarafından açıklandığı sorusu önemli hale gelmiştir. Bu karmaşık ve tartışmalı sorunun birçok iktisatçı tarafından ele alınması sonucunda, piyasa rekabeti ve verimlilik arasındaki ilişkiye yönelik iki farklı yaklaşım ortaya çıkmıştır. Birinci yaklaşım, rekabetçi yapının olduğu bir piyasa ortamında şiddetli rekabet baskısı ile karşılaşan firmaların hayatta kalabilmeleri için verimlilik düzeylerini artırmaları gerektiği varsayılmaktadır. íkinci görüş ise daha düşük rekabetçi bir piyasada daha yüksek piyasa gücüne sahip firmaların yeniliklerin etkisini daha iyi karşılayabileceklerini varsaymaktadır. Piyasa ilişkilerinin karmaşıklı̆ı ve özellikleri, daha önce yapılan çalışmaları tamamlayıcı şekilde verimlilikteki farklııkları ortaya çıkaran piyasa rekabetinin veya piyasa gücünün etkilerinin ampirik olarak incelenmesini gerektirmektedir. OECD verilerine dayanarak ülkeler arası verimlilik karşılaştırması yapan Baily ve Solow (2001), farklı piyasa yapılarından kaynaklı olarak ülkeler arası verimlilik düzeylerinde büyük farklııklar olduğunu ortaya koymuşlardır.

Piyasa rekabetinin verimlilik üzerindeki etkisinin analizi, tekelci rekabetin doğal sonucunun "rahat yaşam" olduğunu savunan Hicks (1935)'in çalışmasına dayanmaktadır. Hicks (1935)'in çalışmasından bu yana farklı teoriler bu konuda alternatif tartışmalar ortaya atmıştır. Schumpeter (1943), piyasa gücü ile verimlilik arasında pozitif doğrusal bir ilişki olduğunu öne sürerken, Arrow (1962) piyasa gücü ile verimlilik arasında pozitif monotonik olmayan dışbükey ilişkinin varlığını ortaya koymaktadır. Piyasa yapısı ile verimlilik arasındaki ilişkiyi inceleyen çok sayıda çalışma olmasına rağmen, daha önce ortaya atılan teorik beklentileri ampirik yaklaşımlarla test eden literatür incelendiğinde net bir görüş birliğine ulaşılamadığı anlaşılmaktadır. Rekabetin verimlilik üzerindeki etkisi farklı çalışmalarda farklı görüşler çerçevesinde ele alınmaktadır. Farklı yazarlara ait birçok çalışmada (Aghion, Bloom, Blundell, Griffith ve Howitt, 2005; Amable, Ledezma ve Robin, 
2016), rekabetin verimlilik üzerindeki negatif etkisi temel Endüstriyel Organizasyon modelleri çerçevesinde "Schumpeter etki" ile açıklanmaktadır. Bu etki aynı zamanda ampirik kanıtlarla da desteklenmektedir (Aghion ve Howitt, 1992; Hashmi, 2013). Bununla birlikte, birçok çalışmada rekabetin verimlilik üzerindeki etkisi "rekabetten kaçış etkisi" çerçevesinde incelenmektedir. Bu görüşe göre, kâr marjlarını artırmak isteyen firmaların, rekabet artışına bağıı olarak verimlilik düzeylerini arttırma eğiliminde oldukları varsayılmaktadır.

Bu çalışmada rekabetin verimlilik üzerindeki etkisi mikro veriler kullanılarak firma düzeyinde analiz edilmektedir. Firmaların rekabet düzeyini temsil eden değişkene ait gösterge Lerner indeksi yaklaşımı ile ölçülmektedir. Toplam faktör verimliliği (TFP) ise, firmanın maliyet fonksiyonu üzerinden stokastik sınır analizi (SFA) yöntemi kullanılarak tahmin edilmektedir. Rekabet düzeyi ve TFP büyümesi arasındaki ilişkinin analizinde, dinamik doğrusal olmayan panel veri tekniği kullanılarak tahminler yapılmaktadır.

Çalışma iki yönden literatüre katkı sağlaması beklenmektedir. Birincisi, toplam faktör verimliliğinin tahmininde genellikle parametrik olmayan indeksler ve doğrusal programlamaya dayalı parametrik olmayan yöntemler kullanılmaktadır. Bu çalışmada ise, parametrik bir yöntem (SFA) kullanılarak ekonometrik tahmin içeren bir yaklaşım izlenmektedir. Böylece, firmanın kontrolü dışında olan stokastik hatalar da tahmin sürecine dahil edilmektedir. Ayrıca, literatürde genellikle üretim fonksiyonu üzerinden TFP tahmini yapılmaktadır. Ancak, bu yaklaşımda girdi fiyatlarına yönelik bilgi olmadığı için maliyet faktörü göz ardı edilmektedir. Bu çalışmada ise, faktörlerin fiyatları üzerinden tanımlanan maliyet fonksiyonu yaklaşımı kullanılarak TFP tahmini yapılmaktadır. íkincisi, rekabetin TFP büyümesi üzerindeki etkisi genellikle doğrusal ve statik panel veri yöntemleri ile analiz edilmektedir. Bu çalışmada literatürden farklı olarak, dinamik etkiyi de içeren doğrusal olmayan panel veri yöntemi kullanılmaktadır. Böylece, rekabet ve TFP büyümesi arasındaki dinamik ilişki, eşik değişken ile tanımlanan faklı rejimlere göre ortaya konmaktadır.

Çalışmanın devam eden kısımları şu şekilde planlanmıştır: ikinci kısımda, çalışmanın temelini oluşturan rekabet ve toplam faktör verimliliği arasındaki teorik ilişki aktarılmaktadır. Üçüncü kısımda, konuya yönelik literatür bulguları özetlenmektedir. Dördüncü kısımda, veri seti ve kullanılan ampirik yöntemler açıklanmaktadır. Beşinci kısımda, araştırmanın sonuçlarına yönelik ampirik bulgular ortaya konulmaktadır. Son olarak, genel sonuçlar ve önerilerle birlikte çalışma tamamlanmaktadır.

\section{Rekabet ve Toplam Faktör Verimliği Arasındaki Teorik ilişki}

Schumpeter (1942) ve Arrow (1962)'un ilk çalışmalarıyla başlayan, ürün piyasa rekabeti ile verimlilik artışı arasındaki ilişki, yeni içsel büyüme teorileriyle en son noktaya ulaşmıştır. Schumpeter (1942)'e göre, piyasa rekabeti firmanın tekelci rantlarını azaltarak yenilik kanalı yoluyla verimlilik artışını etkilemektedir. Bir endüstrinin/sektörün önemli bir teknolojik etkinlik düzeyine ulaşmasını sağlayacak pozitif rekabet etkisi Schumpeter (1942) tarafından ciddi şekilde eleştirilmektedir. Schumpeterci görüşe göre, teknolojik yenilik ve ilerlemenin temel itici gücü ölçek büyüklüğüdür. Diğer bir ifadeyle, sadece önemli piyasa gücü (SMP) ile karakterize edilen oligopolistik sektörler, yüksek düzeyde yenilik ve ARGE elde etmek için büyük teknolojik ilerlemeler üstlenen firmalar için yeni kaynakların ve teşviklerin sağlanmasını garanti eder. Bu durum, endüstriyel organizayon (IO) literatüründe, daha fazla rekabetin kârları azalttığııı iddia eden ve dolayısıyla teknolojik olarak birbirine yakın firmalardan oluşan bir sektörde yenilik yapmaya olan isteğin daha az olduğunu savunan "Schumpeter etkisi" olarak bilinmektedir. Arrow (1962) ise, rekabetçi piyasada yer alan firmaların maliyetleri düşüren teknolojik ilerlemeleri yakalamada genellikle tekelci firmalara göre daha istekli olduğunu belirtmektedir. Daha açık ifadeyle, rekabetçi firmalar tekelci firmaların sahip olduğu statüyü elde etmek ve yenilikçi bir teknolojiye sahip olup tekelci kârı elde etmek için yenilik yapmaya istekli olmaktadırlar. Aksine, tekelci firmalar kendi teknolojik ilerlemelerini başardıktan sonra bile bulundukları konumda kalmayı tercih etmeleri nedeniyle, yenilik yapma eğilimlerinde azalma olacaktır. Tekelci firmalarda bu mekanizma genellikle "yerine koyma etkisi" (replacement effect) olarak adlandırılmaktadır.

Tam rekabetçi piyasaların yukarıda belirtilen "statik" etkinlik varsayımının aksine, Schumpeter (1942) "dinamik" problemin önemine vurgu yapmaktadır. Schumpeter (1942), rekabetçi piyasalarda faaliyet gösteren geleneksel firmaların, daha yoğunlaşmış piyasalarda faaliyet gösteren büyük firmalar kadar dinamik olarak etkin olmadıkları sonucuna ulaşmaktadır. Schumpeter (1942)'in çalışması, yenilikçi faaliyetin 
ilerlemesinde tekel gücünün belirleyici olduğunu düşünen sonraki iktisatçılar tarafından "Schumpeterci hipotez" olarak yeniden yorumlanmıştır. Schumpeter (1942)'in çalışmalarından hareketle birçok iktisatçı, Schumpeter hipotezinin geçerli olup olmadığını teorik ve ampirik çalışmalarla sınamışladır. Yazarlar, özellikle rekabetin (veya tekel gücünün) büyümeyi, teknolojik ilerlemeyi ve yenilikleri hızlandırıp hızlandırmadığı sorularına cevap aramışlardır.

Rekabet ve verimlilik arasındaki ilişkiyi değerlendirmede yaygın olarak kullanılan diğer bir yaklaşım sözleşme teorisi yaklaşımıdır (Dasgupta ve Stiglitz, 1980; Gilbert ve Newbery, 1982). Hart (1983) ürün piyasasındaki rekabetin yönetsel gevşeklikleri (slack) azalttığını ve verimliliği arttırdığını öne sürmektedir. Buna karlıık, Scharfstein (1988), bir işletme yöneticisinin verimliliği yüksek iken düşük verimlilik numarası yapmasının daha kârlı olduğunu gerekçe göstererek piyasa rekabetinin teşvik sorunlarını şiddetlendirebileceğini savunmaktadır. Schmidt (1997)'e göre artan rekabet, firmaların kârlarını azaltıp yöneticileri iflastan korumak için daha fazla çalışmaya zorlarken, kâr oranlarındaki azalışın da maliyet düşüren kârlılığı bozduğunu göstermektedir. Aghion vd. (2005) teorik olarak, toplam inovasyon ve rekabet derecesi arasındaki ilişkinin tersine çevrilmiş $U$ şeklini alabileceğini kanıtlamaktadır. Yazarlar, ters $U$ şeklinin hem "rekabetten kaçış etkisi" hem de "Schumpeter etkisi"nin ortak bileşeninden kaynaklandığını ortaya koymaktadır.

\section{Literatür}

Endüstriyel alanda, firma düzeyinde verimliliği belirleyen değişkenleri inceleyen geniş bir literatür bulunmaktadır. Arrow (1962), Gilbert ve Newbery (1982) ve Aghion ve Howitt (1992)'in öncü teorik çalışmalarından bu yana, söz konusu konu; endüstriyel organizasyon, yönetim ekonomisi ve finans gibi birçok alanda iktisatçılar için önem kazanmıştır. Sonuç itibariyle, bu alanda araştırmacılar ve akademisyenler tarafından önemli ampirik kanıtlar sunulmuştur (Nickell, 1996; Schmitz, 2005; Aghion vd., 2005; Correa, 2012; Hashmi, 2013; Correa ve Ornaghi, 2014; Raymond, Mairesse, Mohnen ve Palm, 2015; Kancs ve Siliverstovs, 2016; Baumann ve Kritikos, 2016; Hashmi ve Biesebroeck, 2016).

Endüstriyel organizasyon (IO) literatüründe rekabet ve verimlilik arasındaki ilişkiyi açıklayan iki farklı görüş bulunmaktadır. Birinci görüş, sektördeki rekabet ve verimlilik arasındaki ilişkinin yönünü açıklamak için standart neoklasik üretim fonksiyonu modellerine ve parametrik tekniklere dayanmaktadır (Solow, 1956). Bu çalışmalar, piyasa yapısı ile yenilik veya verimlilik arasında pozitif (Nickell, 1996; Blundell, Griffith ve Reenen, 1999; Schmitz, 2005; Correa, 2012; Correa ve Ornaghi, 2014) veya negatif (Arrow, 1962; Aghion ve Howitt, 1992; Hashmi, 2013) doğrusal bir ilişkinin varlığını desteklemektedir. Negatif (pozitif) ilişki, verimlilik artışı veya yenilik arayışlarının daha yüksek kâr beklentisine dönüşmesi halinde, rekabetteki bir artışın (azalışın) yeniliği azaltacağı (artıracağı) varsayımını doğrulamaktadır (Hashmi, 2013). Bununla birlikte literatürde, Schumpeterci görüş çerçevesinde rekabet ve yenilik arasında ters $U$ şeklinde ve monoton olmayan bir ilişkiyi ortaya koyan çalışmalar da (Scherer ve Ross, 1990; Mukoyama, 2003; Aghion vd., 2005) bulunmaktadır.

Nickell (1996) tarafından yapılan çalışma, rekabet ve verimlilik artışı arasındaki ilişkiyi araştıran ilk çalışmalardan birisidir. Yazar, 1972 ve 1986 yılları arasında İngiltere'de faaliyet gösteren yaklaşık 700 imalat sanayi firmasını ele alarak yaptığı çalışmasında; piyasa payı, piyasa yoğunlaşması, Lerner indeksi ve rakiplerin sayısı gibi piyasaya özgü faktörleri bir üretim fonksiyonunda, bağımsız değişkenler olarak kullanarak bu faktörlerde meydana gelen bir değişmenin TFP büyümesini nasıl etkilediğini araştırmıştır. Çalışmanın bulguları, piyasa payının temsil ettiği piyasa gücünün TFP seviyesini düşürdüğünü ve Lerner endeksinin temsil ettiği piyasa rekabetinin daha yüksek TFP büyüme oranları ile ilişkili olduğunu ortaya koymaktadır. Geroski (1990), Birleşik Krallık'ta faaliyet gösteren 73 endüstriyel sektörün 1970 ve 1979 dönemine ait verilerini kullanarak yaptığı çalışmada, piyasa yoğunlaşmasındaki artışın yenilik sayısını düşürdüğü bulgusuna ulaşmıştır. Yazar bu bulgunun, Schumpeter hipotezini destekler nitelikte olmadığını belirtmektedir. Haskel (1991), İngiltere verilerine dayanarak yaptığı çalışmada, yoğunlaşma oranındaki düşüş ile verimlilik artışı arasında görülen pozitif ilişki nedeniyle, yüksek piyasa gücünün etkinsizliğe neden olup verimlilik düzeyini düşürdüğü bulgusuna ulaşmıştır. Aghion ve Schankerman (2004), rekabeti arttırıcı politikaların verimliliği arttırabileceğini gösteren teorik kanıtlar sunmaktadır. Carlin, Schaffer ve Seabright (2004), Geçiş ülkeleri üzerine yaptıkları çalışmada; piyasa gücünü gösterge olarak kullandıkları analizde rekabet ve verimlilik 
arasında pozitif doğrusal bir ilişkiye ulaşırlarken, piyasa payını kullanarak yaptıkları analiz sonucunda ters $U$ şeklinde bir ilişkiye ulaşmışlardır. Okada (2005), Nickell (1996)'in uygulamalı çalışmasındaki yaklaşımını izleyerek 1994 ve 2000 yılları arasında yaklaşık 100.000 imalat firmasının verileri ile yaptığı çalışmasında, endüstri düzeyinde daha düşük Lerner indeksi ile ölçülen rekabetin verimlilik artışını güçlendirdiği; buna karşıık, firma düzeyinde Lerner endeksi veya piyasa payının ARGE yapan firmaların verimlilik düzeylerini negatif yönde etkilediği bulgusuna ulaşmıştır. Arai (2005), 1970 ve 1998 yılları arasında endüstriyel alanda bulunan toplam 84 sektör için rekabet gücü ile TFP büyüme oranı arasındaki ilişkiyi araştırmıştır. Japonya Endüstriyel Verimlilik veri tabanı üzerinden yapılan analizler sonucunda, birçok sektörün Lerner indeksi ile TFP büyüme oranı arasında pozitif korelasyon ilişkisine rastlanırken, test $U$ ilişkisi neredeyse hiç gözlemlenmemiştir. Bu sonuçtan hareketle, Arai (2005), rekabetin verimlilik üzerinde pozitif bir etkisinin olamayabileceği sonucuna varmaktadır. Kato (2009), Hint imalat sanayi firmalarının piyasa payı göstergelerini kullanarak, $\mathrm{HHI}$ endeksinin toplam faktör verimliliği büyüme oranı üzerinde pozitif etkisinin olduğunu göstermiştir. Pant ve Pattanayak (2010), ürün piyasası rekabetinin firma düzeyinde verimlilik üzerinde pozitif etkisinin olduğu sonucuna ulaşmış ve ayrıca, rekabet yoğunlaştıkça firma sahipliğinin verimlilik üzerindeki etkisinin güçlendiği göstermiştir. Flath (2011), 1961-1990 yılları arasında endüstri düzeyinde veriler kullanarak yaptığı çalışmasında, Herfindahl endeksi ile ölçülen piyasa yoğunlaşması ile teknolojik büyüme arasında U şeklinde bir ilişki olduğunu, ancak Lerner indeksi ile benzer ilişkiye ulaşılamadığını göstermiştir. Inui, Kawakami ve Miyagawa (2012), 1997 ve 2003 yılları arasında Temel işletme Faaliyetleri Araştırması (BSBAE) tarafından üretilen yaklaşık 35.000 gözlemin oluşturduğu firma düzeyinde veriler ile Japon imalat firmaları üzerine yaptıkları çalışmada, Aghion vd. (2005)'nin çalışmalarına benzer şekilde ters U şeklindeki teoriyi destekleyici nitelikte bulgulara ulaşmışlardır. Aghion (2017), pozitif rekabetten kaçış etkisi ve negatif cesaret kırıcı etki nedeniyle, rekabetin verimlilik üzerinde doğrusal olmayan etkisinin olduğunu öne sürmektedir. Chen, Polemis ve Stengos (2018), ABD imalat sanayinde piyasa yapısı ve toplam faktör verimliliği arasındaki ilişkiyi mikro veri seti kullanarak 1958-2007 dönemi için analiz etmişlerdir. Model katsayılarının tahmininde, açıklayıcı içsel değişkenler ile eşik değişkeni birlikte dikkate alan havuzlanmış panel eşik GMM modeli kullanıımıştır. Eşik değişkeni olarak firmanın yoğunlaşma oranı (CR4) üzerinden yapılan analizler sonucunda, piyasa yapısı ve toplam faktör verimliliği arasında ters-U şeklinde doğrusal olmayan bir ilişki tespit edilmiştir. Polemis (2020) çalışmasında, piyasa rekabetinin toplam faktör verimliliği üzerindeki etkisini 462 ABD imalat sanayi sektöründe 1958-2009 dönemleri için panel kantil regresyon yöntemi kullanarak analiz etmiştir. Yazar yapılan analiz sonucunda, piyasa rekabeti ile toplam faktör verimliliği arasında monoton olmayan ters-U şeklinde bir ilişkiye ulaşmıştır. Yazar, eşik noktadan sonra (global maksimum) piyasa yoğunlaşma arttıkça, tekelci rantın artı̆̆ını; artan tekelci rantla birlikte piyasaya girişlerin kısıtlanması sonucunda rekabetin azalarak toplam faktör verimliliği büyüme oranını düşürdüğünü göstermiştir.

\section{Veri Seti ve Metodoloji}

Bu kısımda çalışmanın veri seti ile toplam faktör verimliliği ve rekabet göstergelerinin elde edilmesinde izlenen yöntemler açıklanmaktadır. Ayrıca, tanımlanan modelin yanı sıra model tahmin yöntemi hakkında da bilgi verilerek bu kısım tamamlanmaktadır.

\subsection{Veri Seti ve Tanımlayıcı İstatistikler}

Çalışmada kullanılan girdi ve çıktı değiş̧enleri 2011-2019 yılları arasında Borsa İstanbul'da işlem gören imalat sektörü firmalarından oluşmaktadır. Firma düzeyinde yıllık veriler, Kamuyu Aydınlatma Platformu'nda (KAP) yer alan firmalara ait bilanço ve gelir tablolarından elde edilmiştir. TFP büyümesini tahmin etmek amacıyla, ilk olarak 97 firmaya ait bir örnekleme ulaşılmıştır. Ancak firmalara ait eksik değer içeren gözlemler ile negatif girdi değerlerine sahip gözlemler veri setinden çıkartılmıştır. Ayrıca, analizde kullanılan yöntem dengeli panel veri setine uygulanabildiği için tüm yıllara ait düzenli verisi bulunmayan firmalar da zorunlu olarak örneklem dışında bırakılmıştır. Bu kısıtlar altında sonuç itibariyle, $77^{1}$ firmaya ait dengeli panelden oluşan ve toplamda 693 gözlemin yer aldığı bir örneklem büyüklüğü analize dahil edilmiştir.

Çalışmada toplam faktör verimliğinin hesaplanmasında maliyet fonksiyonu yaklaşımından yararlanılmaktadır. Maliyet fonksiyonu oluşturulurken bağımlı değişken olarak toplam giderler (TC), bağımsız 
değişkenler olarak çıktı (Y) ve girdi değişkenleri (W) kullanılmaktadır. Çalışmada çıktı değişkeni olarak, firmanın satış değerleri alınmıştır. Girdi değişkenleri ise finansal sermaye, fiziki sermaye ve işgücü şeklinde belirlenmiştir. Maliyet fonksiyonunda kullanılmak üzere girdi değişkenleri üzerinden girdi fiyatları belirlenmiştir. Buna göre, literatürde yer alan çalışmalardan hareketle, finansal sermayenin fiyatını temsilen faiz giderlerinin toplam borçlara oranı, fiziki sermayenin fiyatını temsilen amortisman giderlerinin maddi duran varlıklara oranı ve işgücünün fiyatını temsilen personel giderlerinin personel sayısına oranı kullanılmıştır. Tüm parasal değişkenler baz yıl olarak 2015 tüketici fiyatları endeksi kullanılarak fiyat etkisinden arındırımıştır. Ayrıca, maliyet fonksiyonu tahmin edilmeden önce tüm değişkenler logaritmik forma dönüştürülmüştür. Tablo 1'de TFP büyümesinin hesaplanmasında kullanılan girdi ve çıktı değişkenlerine ait tanımlayıcı istatistik değerleri yer almaktadır.

Tablo 1. Girdi ve Çıktı Değişkenlerine Ait Tanımlayıcı İstatistikler

\begin{tabular}{|l|l|l|l|l|}
\hline \multicolumn{1}{|c|}{ Değişkenler } & \multicolumn{1}{c|}{ Ortalama } & \multicolumn{1}{c|}{ Std.Sapma } & \multicolumn{1}{c|}{ Min } & \multicolumn{1}{c|}{ Mak } \\
\hline TC= Toplam maliyet & $217.057 .756,31$ & $606.298 .345,99$ & $575.599,01$ & $6.545 .013 .716,10$ \\
\hline Y= Satış değerleri & $233.708 .196,37$ & $639.475 .193,65$ & $97.307,66$ & $6.551 .583 .253,58$ \\
\hline W $_{1}=$ Finansal sermaye fiyatı & 0,679 & 10,580 & 0,019 & 250,409 \\
\hline W $_{2}=$ Fiziki sermaye fiyatı & 14,952 & 15,175 & 0,601 & 192,250 \\
\hline W $_{3}=$ Iş̧ücünün fiyatı & $6.780,692$ & $3.623,962$ & 189,750 & $29.358,570$ \\
\hline
\end{tabular}

\subsection{Toplam Faktör Verimliliğin Ölçülmesi: Maliyet Fonksiyonu Yaklaşımı}

Toplam faktör verimliliği (TFP) büyümesinin ölçülmesi ve bileşenlerine ayrıştırılması, endüstriyel verimlilik üzerine yapılan birçok uygulamalı araştırmanın konusu olmuştur (Jorgenson, 1995). TFP büyümesinin ölçülmesinde farklı yaklaşımlar vardır. Literatürde kullanılan farklı yaklaşımlar Diewert, Caves ve Christensen (1982) tarafından şu şekilde sınıflandırılmaktadır: Üretim ve maliyet fonksiyonlarının parametrik tahmini, parametrik olmayan indeksler, kesin indeks sayıları ve doğrusal programlamaya dayalı parametrik olmayan yöntemler. Parametrik olmayan yaklaşımlar arasında yer alan Divisia endeksi, zamana ve mekâna göre TFP büyümesinin ölçümünde yaygın olarak kullanılmaktadır. Bu yaklaşımın en önemli avantajı, herhangi bir ekonometrik tahmin gerektirmemesidir. Bununla birlikte, TFP büyümesi, teknik değişim, ölçeğe göre getiri ve etkinlik değişimi gibi kaynaklarına ayrıştırılmak isteniyorsa, temel teknolojinin ekonometrik tahmini gerekmektedir.

TFP büyümesinin hesaplanmasında kullanılan geleneksel Divisia endeksi şu şekilde tanımlanmaktadır:

$$
\begin{aligned}
& T \dot{F} P=\dot{y}-\dot{F}, \text { burada } \\
& \dot{F}=\sum_{i} \frac{w_{i} x_{i}}{C} \dot{x}
\end{aligned}
$$

Burada $y$ gözlemlenen çıktıyı, $F$ gözlemlenen girdi kullanımının toplu ölçümünü, $w_{i} i$-ninci girdinin fiyatını, $x_{i} i$-ninci girdinin gözlemlenen kullanımını ve $C$ gözlemlenen maliyeti göstermektedir.

TFP ayrıştırması ilk olarak tek-ürünlü firma durumu için türetilmekte, daha sonra çok ürünlü firma için genelleştirilmektedir. Tek-ürünlü maliyet sınır fonksiyonu aşağıdaki gibi ifade edilebilir:

$$
C^{*}=C(y, w, t)
$$

Burada $C^{*}$ maliyet fonksiyonunu oluşturan değişkenler $(y, w, t)$ veri iken, etkin maliyeti göstermektedir. Farrell (1957)'in yaklaşımından hareketle, girdi eksenli genel maliyet etkinliği ölçümü şu şekilde tanımlanabilir: 


$$
E=\frac{C(y, w, t)}{C} \text {, burada } 0<E \leq 1
$$

Girdi eksenli genel etkinlik ölçümünden hareketle aşağıdaki eşitlik elde edilebilir:

$$
E=T * A
$$

Burada $T$ ve $A$, Farrell (1957)'in girdi eksenli yaklaşımına göre elde edilen teknik etkinlik ve tahsis etkinliği değerleridir. Eşitlik 5, daha sonraki eşitliklerde de kullanılmak üzere aşağıdaki gibi yeniden yazılabilir

$$
\dot{E}=\dot{T}+\dot{A}
$$

TFP büyümesinin ayrıştırılması maliyet fonksiyonu yaklaşımı kullanılarak türetilebilir. Eşitlik (4)'ün her iki tarafının doğal logaritması alındıktan sonra zamana göre toplam türevi alınıp küçük birkaç düzeltme yapıldıktan sonra aşağıdaki eşitliğe ulaşımaktadır:

$$
\dot{E}=\varepsilon_{c y}(y, w, t) \dot{y}+\sum_{i} \frac{\partial C(y, w, t)}{\partial w_{i}} \frac{w_{i}}{C(y, w, t)} \dot{w}_{i}+\dot{C}(y, w, t)-\dot{C}
$$

Burada $\varepsilon_{c y}(y, w, t)=[\partial \ln C(y, w, t)] / \partial \ln y$ göstermektedir. Eşitlik (1)'deki TFP büyümesi tanımı kullanılarak Eşitlik (7) aşağıdaki gibi yeniden yazılabilir:

$$
T \dot{F} P=\left[1-\varepsilon_{c y}(y, w, t)\right] \dot{y}+\dot{E}-\dot{C}(y, w, t)-\sum_{i} \frac{w_{i} x_{i}(y, w, t)}{C(y, w, t)} \dot{w}_{i}-\sum_{i} \frac{w_{i} x_{i}}{C} \dot{x}_{i}+\dot{C}
$$

Eşitlik (8) türetilirken aşağıdaki tanımlamalar dikkate alınmaktadır:

$$
\begin{aligned}
& C=\sum_{i} w_{i} x_{i} \\
& \frac{d C}{d t}=\sum_{i} w_{i} \frac{d x_{i}}{d t}+\sum_{i} x_{i} \frac{d w_{i}}{d t} \\
& \dot{C}=\sum_{i} \frac{w_{i} x_{i}}{C} \dot{x}+\sum_{i} \frac{w_{i} x_{i}}{C} w_{i} \\
& \sum_{i} \frac{w_{i} x_{i}}{C} \dot{x}=\dot{C}-\sum_{i} \frac{w_{i} x_{i}}{C} w_{i}
\end{aligned}
$$

Eşitlik (12)'nin eşitlik (8)'de yerine yazılması sonucunda eşitlik (13) elde edilmektedir:

$$
T \dot{F} P=\left[1-\varepsilon_{c y}(y, w, t)\right] \dot{y}+\dot{E}-\dot{C}(y, w, t)+\sum_{i}\left[\frac{w_{i} x_{i}}{C}-\frac{w_{i} x_{i}(y, w, t)}{C(y, w, t)}\right] \dot{w}
$$

Eşitlik (6)'nın eşitlik (13)'de yerine konulup birkaç küçük düzeltme yapıldıktan sonra, gözlemlenen TFP'nin tek-ürünlü maliyet fonksiyonu ayrıştırmasına ulaşımaktadır:

$$
T \dot{F} P=\left[1-\varepsilon_{c y}(y, w, t)\right] \dot{y}+\dot{T}-\dot{A}-\dot{C}(y, w, t)+\sum_{i}\left[s_{i}-s_{i}(y, w, t)\right] \dot{w}
$$

TFP büyümesi, maliyet fonksiyonu üzerinden tahmin edildikten sonra Eşitlik (14) kullanılarak şu şekilde ayrıştırılabilir: Ölçek, $(y, w, t) ; \mathrm{TC},-\frac{\partial \ln C}{\partial t} ; \mathrm{TEC},-\frac{\partial \eta}{\partial t}$

Burada $(y, w, t)$ ölçek getirisini, TC, teknik ve tahsis etkinliğindeki değişimleri ve (TEC), teknolojik ilerlemedeki değişimleri göstermektedir. 


\subsection{Rekabetin Ölçümü: Lerner İndeksi Yaklaşımı}

Piyasa gücü, bir firmanın (veya bir grup firmanın) bir mal veya hizmetin fiyatını rekabetçi seviyenin üzerine çıkarma kabiliyeti olarak tanımlanır. Piyasa gücünün yaygın olarak kullanılan bir ölçüsü, Lerner (1934) tarafından önerilen Lerner indeksidir:

$$
L_{i t}=\frac{P_{i t}-M C_{i t}}{P_{i t}}
$$

Burada $P_{i t}, i$ firmasının $t$ yılındaki çıktı fiyatını göstermektedir. $M C_{i t}$ ise firmanın marjinal maliyetini ifade etmektedir. Burada, fiyat değişkeni toplam gelirin çıktı değişkenine bölümü ile elde edilirken, MC değişkeni aşağıdaki gibi tanımlanan bir maliyet fonksiyonunun tahmin edilmesi sonucunda elde edilmektedir.

$$
\frac{P Y}{C}=\beta_{Y}+\beta_{Y Y} \ln Y+\beta_{Y T} T+\sum_{j=1}^{J-1} \beta_{j Y} \ln \frac{w_{j}}{w_{k}}+u+e
$$

Kumbhakar, Baardsen ve Lien (2012) modelin başlangıç noktasını, endüstride yer alan firmaların fiyatı $(P)$ marjinal maliyetin $(M C)$ üzerinde belirleyerek oligopolistik güç kullandıkları varsayımına dayanan eşitsizlik $(P>M C)$ ile tanımlamışladır. Eşitsizliğin her iki yanının $\frac{Y}{C}$ ile çarpılması sonucunda (burada $Y$ çıktıyı ve $C$ üretim maliyetini göstermektedir) aşağıdaki eşitliğe ulaşılmaktadır:

$$
\frac{P Y}{C}=\frac{\partial \ln C}{\partial \ln Y}+u, \quad u \geq 0
$$

Burada $\frac{P Y}{C}$ üretim maliyeti içindeki satış gelirinin payını, $\frac{\partial \ln C}{\partial \ln Y}$ ölçek esnekliğini ve $u$ sektördeki fiyat artışını ölçen, negatif olmayan tek taraflı bir terimdir. Kumbhakar vd. (2012), $u$ teriminin teknik etkinsizlikle ilişkili negatif olmayan tek taraflı rassal bir değişken olduğunu göstermektedir. Burada negatif olmayan $u$ terimi istatistiksel olarak anlamlıysa, endüstride piyasa gücünün varlığına dair kanıtların olduğu sonucuna ulaşılabilir. Çalışmada piyasa gücünü tahmin etmek amacıyla, maliyet fonksiyonu tanımından yararlanılmaktadır. Standart bir translog maliyet fonksiyonu aşağıdaki gibi tanımlanabilir (Kumbhakar vd., 2012):

$$
\begin{aligned}
\ln C= & \beta_{0}+\beta_{Y} \ln Y+\frac{1}{2} \beta_{Y Y}(\ln Y)^{2}+\beta_{Y T} T \ln Y+\beta_{T} T+\frac{1}{2} \beta_{T T} T^{2}+\sum_{j=1}^{J} \beta_{j} \ln W_{j} \\
& +\sum_{j=1}^{J} \sum_{k=1}^{K} \beta_{j k} \ln W_{j} \ln W_{k}+\sum_{j=1}^{J} \beta_{j Y} \ln W_{J} \ln Y+\sum_{j=1}^{J} \beta_{j T} T \ln W_{j}
\end{aligned}
$$

Burada, $\ln C$ toplam maliyetlerin logaritmasını; $\ln Y$ çıtıtı düzeyinin logaritmasını; $W^{\prime}$ ler girdi fiyatlarını göstermektedir. Eşitlik (18), simetri ve doğrusal homojenlik kısıtları altında tanımlanmaktadır. Simetri koşulu, $\beta_{j k}=\beta_{k j}$ eşitliği ile sağlanmaktadır. Homojenlik koşulunun sağlanması için, tüm girdi fiyatları $k$ girdisinin fiyatına göre normalleştirilmektedir.

Simetri ve homojenlik koşulları uygulandıktan sonra, firmanın satış değerlerinin logaritmasına (ln $Y$ ) göre Eşitlik (18)'in türevi alınmaktadır:

$$
\frac{\partial \ln C}{\partial \ln Y}=\beta_{Y}+\beta_{Y Y} \ln Y+\beta_{Y T} T+\sum_{j=1}^{J-1} \beta_{j Y} \ln \frac{W_{j}}{W_{k}}
$$

Eşitlik (19)'un Eşitlik (16)'da yerine konulması sonucunda, stokastik kar maksimizasyonu denklemine ulaşılmaktadır:

$$
\frac{P Y}{C}=\beta_{Y}+\beta_{Y Y} \ln Y+\beta_{Y T} T+\sum_{j=1}^{J-1} \beta_{j Y} \ln \frac{w_{j}}{w_{k}}+u+e
$$


Eşitlik (20)'de yer alan bileşik hata terimi $(u+e)$, stokastik maliyet sınırı modelinden farklı değildir. Eşitlik (20)'nin tahmininde stokastik maliyet sınırının tahmininde yaygın olarak kullanılan maksimum olabilirlik yöntemi kullanılmaktadır. Maksimum olasılık yöntemi, hataların dağılım varsayımına dayanmaktadır. Literatür izlenerek, $u$ ve $e$ terimlerine ilişkin dağılım varsayımları şu şekilde ifade edilebilir: $u$ terimi alttan sıfırda kesitli olan normal bir değişkendir. Yani, $u \sim N^{+}\left(0, \sigma_{u}^{2}\right)$ şeklinde tanımlanabilir. Öte yandan, $e$ terimi iki-yönlü normal gürültü terimi olup, $e \sim N\left(0, \sigma_{e}^{2}\right)$ şeklinde gösterilmektedir.

\subsection{Model Tanımı}

Çalışmada Hansen (1999) tarafından geliştirilen statik modelin, Seo ve Shin (2016) tarafından içsel açıklayıcı değişkenleri içerecek şekilde genişletilmiş dinamik hali kullanılmaktadır. Hansen (1999) tarafından geliştirilen panel eşik modeli, ampirik araştırmalarda yaygın olarak kullanılmakla birlikte, model önemli kısıtlar içermektedir. Birincisi, model statiktir. Bu nedenle, iktisadi değişkenler arasında görülen dinamik ilişkileri göz ardı etmektedir. İkincisi, kullanılan bağımsız değişkenlerin güçlü dışsal değişkenler olmasını gerektirmektedir (Seo ve Shin, 2016). Oysa, iktisadi değişkenlerle kurulan regresyon modellerinde güçlü dışsalık varsayımını sağlamak her zaman kolay değildir. Ayrıca, modelin açıklayıcı değişkenleri arasında bağımlı değişkenin gecikmeli değeri yer alabilir. Bu iki gerekçe nedeniyle, bu çalışmada tahmin yöntemi olarak Seo ve Shin (2016) tarafından geliştirilen yaklaşım kullanıımaktadır. Burada kullanılan yaklaşım, belli bir eşik değerine bağlı olarak çalışmada kullanılan örneklemin iki farklı rejime ayrılmasına dayanmaktadır. Böylece, önceden bilinmeyen bir eşik değerin altında ya da üstünde tanımlanan, rejime bağlı bağımsız bir değişken ile bağımlı değişken arasındaki asimetrik ilişki analiz edilmektedir (Kurul, 2021). Seo ve Shin (2016) tarafından geliştirilen dinamik panel eşik modeli hem eşik değişkenin hem de açıklayıcı değişkenlerin içsel olmasına izin vermektedir. Ayrıca model, bağımlı değişkenin gecikmeli değerinin bağımsız değişken olarak kullanılmasına olanak vermektedir.

Çalışmada rekabet gücünün TFP büyümesi üzerindeki etkisini analiz etmek amacıyla oluşturulan dinamik panel eşik modeli aşağıdaki gibi tanımlanabilir:

$$
\operatorname{TFP}_{i t}=\beta_{0}+\beta_{1} \mathrm{TFP}_{i t-1}+\beta_{2} X_{i t}+\beta_{3}\left(1-\text { Lerner }_{i t}\right)+\delta\left(\left(1-\text { Lerner }_{i t}\right)-\gamma\right) I\left\{\left(1-\text { Lerner }_{i t}\right) \geq \gamma\right\}+\mu_{i}+\varepsilon_{i t}
$$

Burada $i=1, \ldots \ldots N$ analizde yer alan firmaları, $t=1, \ldots \ldots T$ ele alınan zaman dönemini ve $\varepsilon_{i t} \sim \operatorname{iid}\left(0, \sigma^{2}\right)$, sıfır ortalama ve sabit varyansa sahip, bağımsız ve özdeş dağılımlı bir hata terimini ifade etmektedir. Bağımlı değişken $T F P_{i t}, i$ firmasının $t$ dönemindeki TFP büyümesidir. Denklemde yer alan $\mu_{i}$ parametresi firmaya özgü sabit etkileri, $\left(1-\right.$ Lerner $\left._{i t}\right)$ içsel eşik değişken olarak kullanılan rekabet göstergesini, $\gamma$ eşik değerini ve $I($.$) eşik değişkenin eşik düzeyinden daha düşük veya daha yüksek olup$ olmadığına bağıı olarak 1 veya 0 değerini alan bir gösterge fonksiyonudur. Bu fonksiyon, örneklem gözlemlerinin iki gruba ayrılmasını sağlayarak iki farklı rejime ait marjinal etkileri gösteren katsayıların tahmin edilmesine imkân vermektedir.

Dinamik panel veri modellerinde, otoregresif parametrelerin sabit etkiler tahmincisi aşağı yönlü sapmalıdır (Nickell, 1981). Eşitlik (21)'de yer alan bireysel etkiler $\left(\mu_{i}\right)$ ile açıklayıcı değişkenler arasındaki korelasyon, Arellano ve Bond (1991) tarafından önerilen birinci fark tahmincisi ile ortadan kaldırımaktadır. Eşitlik (21)'e birinci fark dönüşümü uygulanması sonucunda aşağıda yer alan eşitlik (22) elde edilmektedir.

$$
\begin{aligned}
\Delta \operatorname{TFP}_{i t}= & \beta_{1} \Delta \mathrm{TFP}_{i t-1}+\beta_{2} \Delta X_{i t}+\beta_{3} \Delta\left(1-\text { Lerner }_{i t}\right)+\delta\left(\left(1-\text { Lerner }_{i t}\right)-\gamma\right) I\left\{\left(1-\text { Lerner }_{i t}\right) \geq \gamma\right\} \\
& -\left(\left(1-\text { Lerner }_{i t}\right)-\gamma\right) \delta I\left\{\left(1-\text { Lerner }_{i t}\right)>\gamma\right\}+\Delta \varepsilon_{i t}
\end{aligned}
$$

Modelde rekabet gücünü temsil eden Lerner indeksi (1-Lerner), hem eşik değişkeni (threshold) hem de rejime bağıı (regime-dependent) açıklayıcı değişken olarak tanımlanmıştır. Lerner indeksi fiyat ve maliyet marjına dayalı bir rekabet göstergesi olduğu için, toplam faktör verimliliği denkleminde kullanılması muhtemel bir içsellik sorununa neden olabilir. Firmanın fiyat-maliyet marjının belli bir ölçüde verimlilik artışı şoklarından kaynaklanabileceği varsayımı göz önüne alınırsa, ortaya çıkabilecek potansiyel içsellik sorununun kontrol edilmesi gerekmektedir. Verimlilik düzeyi arttıkça, firmaların kar beklentileri de artmakta ve bu durum daha fazla firmanın sektöre girmesine ve firma sayısının artmasına neden olmaktadır. Daha fazla 
firmanın sektöre girmesiyle birlikte mevcut firmalar üzerinde oluşan rekabet baskısı, üretim düzeyine bağıı olarak uzun dönem marjinal maliyetin değişmesine neden olur. Bunun sonucu olarak, verimlilikten kaynaklı etkilerin marjinal maliyet ve dolayısıyla rekabet üzerinde etkisinin olması beklenebilir. Bu ise, toplam faktör verimliliği ve rekabet arasında eşanlı bir ilişkinin olması anlamına gelmektedir. Bu çalışmada kullanılan yaklaşım eşik değişkenin içsel olmasına olanak sağladığı için, tahmin aşamasında Lerner indeksi değerlerinden kaynaklı muhtemel içsellik sorunu dikkate alınmış olmaktadır. Bunun için, eşitlik (22)'de yer alan fark denklemi elde edildikten sonra, model Seo ve Shin (2016) tarafından önerilen birinci-fark GMM (FD-GMM) yöntemi kullanılarak tahmin edilmektedir. Burada, araç değişken olarak içsel değişkenin (Lerner indeksi) kendi gecikmeli değerleri kullanılmakta ve böylece içsel değişken hata terimi ile ilişkisiz hale getirilmektedir. Seo ve Shin (2016) tarafından önerilen araç değişken vektörü, $2<t 0 \leq T$ olmak üzere $\left(z_{i t 0}^{\prime}, \ldots, z_{i T}^{\prime}\right)^{\prime}$ olarak tanımlanmıştır (Seo ve Shin, 2016: 5).

Denklemde yer alan $X_{i t}$, rejimden bağımsız kabul edilen kontrol değişkenler vektörünü göstermektedir. Modelde, ölçek büyüklüğü $\left(\operatorname{Size}_{i t}\right)$, sermaye yoğunluğu $\left(\operatorname{Cap}_{\_} i n t_{i t}\right)$, işgücü maliyeti $\left(\operatorname{Cost}_{i t}\right)$ ve firmanın yaşı $\left(A g e_{i t}\right)$ olmak üzere 4 adet kontrol değişkeni kullanılmıştır. Ölçek büyüklüğü, firmaların toplam aktiflerinin logaritması alınarak hesaplanmıştır. Sermaye yoğunluğu, toplam sabit varlıkların toplam aktiflere oranı ile hesaplanmıştır. İşgücü maliyeti ise, toplam personel giderlerinin satışlara oranı ile elde edilmiştir. Son olarak, firmanın deneyim ve tecrübelerinin temsili olarak kullanılan yaş değişkeni, firmanın sektörde faaliyet gösterdiği yıl sayısı olarak hesaplanmıştır. Modelde yer alan kontrol değişkenleri, içsel değişkenler ve dışsal değişkenler olmak üzere iki parçadan oluşmaktadır. Ölçek büyüklüğü, muhtemel içsellik sorunu nedeniyle modelde içsel değişken olarak kullanılmıştır. Diğer değişkenler ise, dışsal kontrol değişkenleri olarak modele dahil edilmiştir.

Denklemde, rekabet ve TFP büyümesi arasındaki ilişki, rekabet gücü eşik değerinin yol açtığı nedensellik çerçevesinde incelenmektedir. Modelde, içsel açıklayıcı değişken olarak firmaların başlangıç TFP $\left(T F P_{i t-1}\right)$ düzeyleri kullanılmaktadır. Gecikmeli bağımlı değişkenin açıklayıcı değiş̧en olarak kullanılmasından dolayı ortaya çıkabilecek içsellik sorunu, Seo ve Shin (2016) tarafından önerilen ve birincifark (FD) dönüşümüne dayanan GMM (FD-GMM) yöntemi ile giderilmektedir. Bu yaklaşımla birlikte, hem doğrusal olmayan asimetrik dinamik ilişkiye hem de gözlemlenmeyen bireysel heterojenliğe aynı anda izin verilmektedir. FD-GMM yönteminde araç değişken olarak içsel değişkenlerin kendi gecikmeli değerleri kullanılmakta ve böylece içsel değişkenlerin hata terimi ile olan ilişkisi ortadan kaldırılmaktadır.

Eşik değer $\gamma$, koşullu en küçük kareler yöntemiyle hesaplanmaktadır. Burada, en küçük hata kareler toplamına $(R S S)$ karşılık gelen değer değer eşik değer olarak belirlenmektedir. Eşik değerin seçiminde, en küçük değerin tespitinde kullanılan $\hat{\gamma}=\operatorname{argmin} S(\gamma)$ formülünden yararlanılmaktadır (Caner ve Hansen, 2004). Modelde eşik değerin anlamlı olup olmadığı, boostrap algoritması kullanılarak Wald testi ile sınanmaktadır. Burada, doğrusallık varsayımı altında tanımlanan boş hipotez $\left(H_{0}: \delta=0\right)$, doğrusal olmayan alternatif hipoteze $\left(H_{1}: \delta \neq 0\right)$ karşı test edilmektedir (Seo ve Shin, 2016).

\section{Ampirik Bulgular}

\subsection{TFP Büyümesi ve Lerner İndeksi Sonuçları (Tanımlayıcı İstatistikler)}

Tablo 2' de imalat sanayinde faaliyet gösteren firmaların yıllar itibariyle verimlilik düzeyleri ile rekabet gücündeki değişimi gösteren ortalama TFP büyüme oranı ve Lerner indeksi değerleri yer almaktadır. Panel $A^{\prime}$ da yer alan tanımlayıc istatistik değerleri incelendiğinde, TFP büyümesi ele alınan zaman döneminde ortalama \%1,6 oranında artış göstermektedir. Fiyat ile marjinal maliyet arasındaki farkın fiyata oranı şeklinde tanımlanan Lerner indeksi değeri ise, ortalama \%35,06 olarak hesaplanmıştır. 
Tablo 2. TFP Büyümesi ve Lerner İndeksi Özet İstatistikleri

\begin{tabular}{|l|c|c|c|c|}
\hline \multicolumn{5}{|l|}{ Panel A: Tanımlayıcı İstatistikler } \\
\hline Değişkenler & Ortalama & Std.Sapma. & Min. & Mak. \\
\hline TFP büyümesi & 0,0164 & 0,0270 & $-0,1904$ & 0,1490 \\
\hline Lerner indeksi & 0,3506 & 0,1077 & $-0,7517$ & 0,8030 \\
\hline Panel B: Yıllara Göre TFP ve Lerner Indeksindeki Değişim \\
\hline Yıllar & \multicolumn{2}{|c|}{ TFP büyümesi } & Lerner Indeksi \\
\hline 2011 & \multicolumn{2}{|c|}{0,0413} & 0,3343 \\
\hline 2012 & 0,0411 & 0,3475 \\
\hline 2013 & 0,0331 & 0,3455 \\
\hline 2014 & 0,0218 & 0,3549 \\
\hline 2015 & 0,0172 & 0,3449 \\
\hline 2016 & 0,0007 & 0,3452 \\
\hline 2017 & 0,0002 & 0,3589 \\
\hline 2018 & $-0,0028$ & 0,3686 \\
\hline 2019 & $-0,0136$ & 0,3558 \\
\hline
\end{tabular}

Not: Lerner indeksi 0 ile 1 arasında değerler almakla birlikte, 1'e doğru yaklaştıkça rekabet gücünün artması anlamına gelmektedir.

Firmaların verimlilik düzeyi ve rekabet gücünün yıllara göre değişimini gösteren Panel B sonuçları incelendiğinde, TFP büyümesinde ele alınan dönem boyunca azalan bir eğilim görülmektedir. Analizin başlangıç dönemi olan 2011 yılı ile 2012 yıllarında \%4 olarak hesaplanan TFP büyüme oranı, 2013, 2014 ve 2015 yıllarında sırasıyla \%3, \%2 ve \%1 oranında azalan bir seyir izlemektedir. 2016 yılından sonra ise, TFP büyüme hızında hızı bir düşüş eğilimi görülmektedir. Son iki yılda (2018 ve 2019) ise TFP büyümesi negatif olarak gerçekleşmiştir. Firmanın rekabet gücünü gösteren Lerner indeksi değerleri ise, ele alınan zaman dönemi boyunca \%33,43 ile \%36,86 arasında değişim göstermektedir. Rekabet düzeyinde önemli bir farklıık olmamakla birlikte, başlangıç dönemiyle (2011) kıyaslandığında, son yıllarda (2017-2019) rekabet gücünün azaldığı (Lerner indeksinin değerinin yükselmesi) ve firmaların kısmen de olsa tekelci bir eğilime sahip oldukları söylenebilir. Tablo 3'te, imalat sanayi alt sektörlerinde faaliyet gösteren firmaların TFP büyüme performansı ve rekabet gücü göstergeleri analiz edilmektedir. Sektörlerin verimlilik düzeylerini gösteren TFP değerleri incelendiğinde, TFP büyüme hızının ortalama \%1,31 (Ana Metal Sanayi) ile \%1,89 (Kimya ilaç Petrol Lastik ve Plastik Ürünler) arasında değiştiği görülmektedir. Buna göre, sektörlerin büyüme hızının birbirine yakın olduğu söylenebilir.

Tablo 3. Sektör Bazında TFP büyümesi ve Lerner İndeksi Ortalamaları

\begin{tabular}{|l|c|c|c|c|}
\hline Sektörler & TFP büyümesi & Sıra & Lerner İndeksi & Sıra \\
\hline Tekstil, Giyim Eşyası ve Deri & 0,0174 & 3 & 0,3435 & 3 \\
\hline Gıda, İçecek ve Tütün & 0,0182 & 2 & 0,3237 & 6 \\
\hline Kâğıt ve Kâğı̈t Ürünleri, Basım ve Yayın & 0,0156 & 4 & 0,3005 & 7 \\
\hline Kimya Ilaç Petrol Lastik ve Plastik Ürünler & 0,0189 & 1 & 0,3871 & 2 \\
\hline Ana Metal Sanayi & 0,0131 & 7 & 0,3382 & 4 \\
\hline $\begin{array}{l}\text { Metal Eşya Makine Elektrikli Cihazlar ve } \\
\text { Ulaşım Araçları }\end{array}$ & 0,0153 & 6 & 0,3274 & 5 \\
\hline Taş ve Toprağa Dayalı & 0,0154 & 5 & 0,4184 & 1 \\
\hline
\end{tabular}

Not: Lerner indeksi 0 ile 1 arasında değerler almakla birlikte, 1'e doğru yaklaştıkça rekabet gücünün artması anlamına gelmektedir.

Öte yandan, sektörler arası rekabet düzeyini gösteren Lerner indeksi değerleri \%30,05 ile \%41,84 arasında değişmektedir. Lerner indeksindeki artış, rekabet düzeyinin düşüşü anlamına geldiği için, en yüksek indeks değerine sahip Taş ve Toprağa Dayalı imalat sanayi alt sektörü, firmalar açısından rekabetin en düşük 
olduğu sektör olarak değerlendirilebilir. Rekabetin en yüksek olduğu sektör ise, en düşük Lerner indeksi değerine sahip Kâğıt ve Kâğıt Ürünleri, Basım ve Yayın imalat alt sektörüdür.

\subsection{Analiz Sonuçları}

Bu kısım çalışmanın ampirik bulgularını ortaya koymaktadır. Çalışmada, Lerner indeksi TFP büyümesini açıklayan temel rekabet gücü göstergesi olarak kullanılmaktadır. Katsayının daha kolay yorumlanabilmesi amacıyla, Lerner indeksi değerleri, rekabet arttıkça indeks değerinin de artacağı şekilde tanımlanarak (1-Lerner) modele dahil edilmiştir. Böylece, Lerner indeksindeki artışa bağlı olarak 1-Lerner değeri, rekabet gücündeki artış şeklinde yorumlanmaktadır.

Tahmin aşamasına geçmeden önce, eşik modelin geçerliliğine yönelik doğrusal olmama testi uygulanmaktadır. Burada uygulanan test yöntemi, değişen varyansa karşı dirençli Wald tipi test istatistiğinin bootstrap kritik değerlerine dayanmaktadır. Boş hipotezin reddi, eşik değerin anlamlı olduğunu ve doğrusal olmayan model yapısının geçerli olduğunu göstermektedir. Buna göre, tabloda yer alan bootstrap olasılık değeri \%5 önem düzeyinde anlamlı olduğu için, doğrusal model reddedilip eşik modelin kabulüne karar verilmektedir.

Tablo 4. Dinamik Eşik Panel Tahmin Sonuçları

\begin{tabular}{|c|c|c|}
\hline \multicolumn{3}{|c|}{$\begin{array}{l}\text { Bağımlı değişken: TFP büyümesi } \\
\text { Eşik Değişken: Rekabet (1-Lerner) }\end{array}$} \\
\hline \multirow[t]{2}{*}{ Eşik değer tahmini $(\hat{\gamma})$} & \multicolumn{2}{|c|}{$0,322 * * *$} \\
\hline & {$[0,284$} & $0,361]$ \\
\hline $\begin{array}{l}\text { Eşik değer anlamlılık testi } \\
\text { (bootstrap p-değeri) }\end{array}$ & \multicolumn{2}{|c|}{0,000} \\
\hline \multirow[t]{2}{*}{ Değişkenler } & \multicolumn{2}{|c|}{ Katsayılar } \\
\hline & $\begin{array}{l}\text { Rejim } 1 \\
(1-\text { Lerner }) \leq \hat{\delta}\end{array}$ & $\begin{array}{l}\text { Rejim } 2 \\
(1-\text { Lerner })>\hat{\delta}\end{array}$ \\
\hline \multicolumn{3}{|l|}{ Rejime bağlı değişken } \\
\hline$(1-$ Lerner $)$ & $\begin{array}{l}0,0004 \\
(0,002)\end{array}$ & $\begin{array}{l}0,017 * * * \\
(0,003)\end{array}$ \\
\hline \multicolumn{3}{|c|}{ Rejimden bağımsız değişkenler } \\
\hline initialTFP $P_{i t}$ & $\begin{array}{l}-0,138^{* * *} \\
(0,006)\end{array}$ & $\begin{array}{l}0,020 * * \\
(0,009)\end{array}$ \\
\hline $\operatorname{Size}_{i t}$ & $\begin{array}{l}-0,002 * * \\
(0,001)\end{array}$ & $\begin{array}{l}-0,013 * * * \\
(0,0006)\end{array}$ \\
\hline Cap_int $_{i t}$ & $\begin{array}{l}0,007 * * * \\
(0,001) \\
\end{array}$ & $\begin{array}{l}0,010 * * * \\
(0,001) \\
\end{array}$ \\
\hline $\operatorname{Cost}_{i t}$ & $\begin{array}{l}-0,074^{* * *} \\
(0,007)\end{array}$ & $\begin{array}{l}-0,064^{* * *} \\
(0,009)\end{array}$ \\
\hline$A g e_{i t}$ & $\begin{array}{l}-0,300 * * * \\
(0,006)\end{array}$ & $\begin{array}{l}0,049 * * * \\
(0,004)\end{array}$ \\
\hline Sabit & $\begin{array}{l}0,057 * * * \\
(0,009)\end{array}$ & $\begin{array}{l}0,057^{* * *} \\
(0,009)\end{array}$ \\
\hline Gözlem Sayısı & $164(\% 24)$ & $529(\% 76)$ \\
\hline
\end{tabular}

Modelde, firmaların rekabet gücünü gösteren eşik değer 0,322 olarak tahmin edilmiştir. Daha yüksek Lerner indeksi değeri (1-Lerner) daha fazla rekabet gücü anlamına geldiği için, eşik değerin üzerinde firmalar için daha yüksek rekabet gücü görülürken; eşik değerin altında rekabet gücü giderek azalmaktadır. Eşik değerin anlamlılı̆ına yönelik yapılan doğrusallık testine göre rekabet ve TFP büyümesi arasındaki ilişkinin 
doğrusal olduğunu öne süren boş hipotez reddedilmektedir. Buna göre, rekabet ve TFP büyümesi arasında doğrusal olmayan asimetrik bir ilişkinin olduğu söylenebilir.

Tabloda eşik değerin atında ve üstündeki olmak üzere iki farklı rejim (Rejim-1 ve Rejim-2) tahmin edilmektedir. Her bir rejime ait eğim katsayısı $(\hat{\delta})$, rekabetin verimlilik üzerindeki eşik değere $(\hat{\gamma})$ göre farklılaşan etkisini (marjinal etki) ortaya koymaktadır. Rejim-1, eşit değere eşit ve eşik değerin altında kalan rekabet düzeylerini göstermektedir. Modelde yer alan eşik değişkeni (1 - Lerner) olarak tanımlandığı için, eşik değerin altında yer alan Rejim-1, düşük rekabet düzeyine karşılık gelmektedir. Buna karşın, eşik değerin üzerinde yer alan Rejim-2, yüksek rekabet düzeyine karşılık gelmektedir. Bu bağlamda, eşik değerin altında (Rejim 1-düşük rekabet), piyasa rekabeti ile TFP büyümesi arasında anlamlı bir ilişkiye ulaşılamamıştır. Öte yandan, eşik değerin üstünde (Rejim 2-yüksek rekabet) tahmin edilen eğim katsayısı $(\hat{\delta})$ katsayısı pozitif ve istatistiksel olarak anlamlı bulunmuştur. Buna göre, eşik değerin üzerinde yer alan firmaların rekabet gücü ile TFP büyümesi arasında pozitif bir ilişki tespit edilmiştir. Bu sonuç, eşik değerin üzerinde rekabet gücündeki artışların TFP büyümesini pozitif yönde etkilediğini göstermektedir. Buna göre, tekelci yapıdan uzaklaşıp, piyasada eşik değerin $(0,322)$ ötesine geçen bir rekabet süreci oluştukça, TFP artı̧̧ eğilimi göstermektedir. Benzer sonuç, Nickell (1996) ve Lanau ve Topalova (2016) tarafından çalışmalarda ortaya konulmaktadır. Piyasa rekabetinin TFP büyümesi üzerindeki pozitif etkisi, rekabetçi bir piyasa yapısı içerinde, üretim sürecinde oluşan aylakların azaltılması ve kaynakların etkin bir şekilde tahsisinin sağlanması yönünde firma yöneticileri üzerinde baskı yaratarak, firmalarda X-etkinsizliğinin azaltılmasına ve bu sayede verimliliğin artmasına katkı sağlamaktadır (Bloom ve Van Reenen, 2010).

Modelde, rejimden bağımsız değişkenler olarak kullanılan kontrol değişkenlerinden; ölçek büyüklüğü $\left(\right.$ Size $\left._{i t}\right)$ her iki rejimde de negatif ve istatistiksel olarak anlamlıdır. Firmaların ölçek büyüklüğü arttıkça TFP büyümesi azalış göstermektedir. Buna göre, ölçek büyüklüğünün sonucunda oluşan yüksek giriş engelleri ve sınırlı rekabet yoğunluğu, tekelci rantları arttırarak firmalar arası rekabetin ortadan kalmasına (piyasaya girişi kısıtlayarak) ve TFP büyüme oranının düşmesine neden olmaktadır. Diğer kontrol değişkenlerinden, sermaye yoğunluğu ( Cap_int $_{i t}$ ) her iki rejimde de TFP büyümesi üzerinde pozitif ve anlamlı etkide bulunmaktadır. Her iki rejim için tahmin edilen işgücü maliyetinin $\left(\operatorname{Cost}_{i t}\right)$ TFP büyümesi üzerinde negatif etkisinin olduğu görülmektedir. Firmanın faaliyet yılını gösteren yaş değişkeni $\left(A g e_{i t}\right)$ ise, birinci rejimde negatif, ikinci rejimde pozitif işaretlidir. Buna göre, rekabet arttıkça, firmaların deneyim ve tecrübelerinden daha fazla yararlanarak verimliliklerini artırdıkları söylenebilir.

\section{Sonuç ve Öneriler}

Rekabet, belirli bir amaca ulaşmayı hedefleyen bireyler, gruplar, firmalar veya uluslar arasındaki rekabet sürecini ifade etmektedir. Rekabet, firmaların daha etkin faaliyette bulunmalarını sağlayıp daha düşük fiyatlarla daha fazla ürün ve hizmet seçeneği sunmaları yönünde teşvik ettiği için, tüketici refahının arttırılmasında ve kaynakların etkin tahsisinin sağlanmasında temel itici güç olarak kabul edilmektedir (OECD, 1993). Rekabetin bu tanımından hareketle iki temel kavram ortaya çıkmaktadır: Birincisi, piyasada yeni veya iyileştirilmiş ürün veya hizmetlerin kullanılmasıyla ilişkili olan ve araştırma ve geliştirme faaliyetleri (ARGE) veya patent süreci yoluyla ölçülebilen yenilik kavramı; ikincisi ise, maliyet düşüşü, ölçek ekonomileri ve düşük fiyatlar ile ilişkili verimlilik kavramıdır. Çalışmada, rekabet ve toplam faktör verimliliği arasındaki ilişki Seo ve Shin (2016) tarafından geliştirilen dinamik panel eşik modeli kullanılarak test edilmektedir.

Çalışmanın veri setini, 2011-2019 dönemleri arasında Türk imalat sanayinde faaliyet gösteren toplam 77 firma için hazırlanan mikro veriler oluşturmaktadır. Rekabet gücünün tahmininde, geleneksel rekabet ölçme yöntemlerinden birisi olan Lerner indeksinden yararlanılmaktadır. Toplam faktör verimliliği ise stokastik sınır analizi (SFA) yöntemi kullanılarak maliyet fonksiyonu üzerinden tahmin edilmektedir. Son olarak, rekabetin toplam faktör verimliliği üzerindeki etkisi, GMM temelli dinamik panel eşik modeli ile analiz edilmektedir.

Tahmin edilen TFP büyüme oranı ele alınan dönem boyunca azalan bir eğilim göstermekle birlikte, özellikle son iki yıl içinde (2018 ve 2019) negatif büyüme oranı göstermektedir. Lerner indeksi değerleri ise, \%33,43 ile $\% 36,86$ arasında değişirken ortalama \%35,06 olarak gerçekleşmiştir. Buna göre, rekabet gücü düzeyinde 
önemli bir değişme olmamakla birlikte, son yıllarda (2017-2019) Lerner indeksinin artmasına bağlı olarak rekabet gücünde azalmanın olduğu söylenebilir. Sektörel TFP büyüme oranları karşılaştırıldığında, ortalama TFP büyüme hızı en düşük olan sektör Ana Metal Sanayi (\%1,31) iken; en yüksek TFP büyümesine sahip sektör Kimya İlaç Petrol Lastik ve Plastik Ürünleridir $(\% 1,89)$. Rekabet gücü açısından, en rekabetçi sektör Kâğıt ve Kâğıt Ürünleri, Basım ve Yayın sektörü iken; en az rekabetin olduğu sektör Taş ve Toprağa Dayalı alt sektördür.

Dinamik eşik panel veri modeli sonucuna göre, içsel olarak tahmin edilen eşik değeri 0,322'dir. Bu eşik değer, piyasadaki rekabet düzeyinin sınırını belirlemektedir. Eşik değerin altında kalan gözlem değerleri birinci rejime karşılık gelmektedir. Bu rejim, düşük rekabet düzeyini tanımlamaktadır. Eşik değerin üzerinde yer alan gözlem değerleri ise, ikinci rejime karşılık gelmekte ve rekabet artışını ortaya koymaktadır. Ampirik bulgulardan hareketle, eşik değerin üzerinde rekabet artışı firmaların verimlilik düzeylerini artırmaktadır. Buna karşın, eşik değerden düşük rekabet düzeylerinde, tekelci piyasa yapısına bağlı olarak firmalar verimlilik düzeylerinde anlamlı bir artışı ortaya koyamamaktadırlar. Bu durumda, düşük rekabet düzeyinde rekabetin faktör verimliliğini arttırabilmesi, tekelci fiyatlandırma yaparken bu firmaların etkinlik ve verimlilik gibi süreçleri dikkate almaları ile gerçekleşebilir.

Çalışmada ulaşılan bulgular literatürde yapılan diğer ampirik çalışmalarda benzerlik göstermektedir. Bu çalışmada olduğu gibi, literatürde yapılan farklı çalışmalarda, rekabet ve toplam faktör verimliliği arasında pozitif ve istatistiksel olarak anlamlı bir ilişkinin olduğu görülmektedir (Nickell, 1996; Schiffbauer ve Ospina, 2010; Lanau ve Topalova, 2016; Satpathy ve Mishra, 2019). Satpathy ve Mishra (2019), Hintli imalat firmaları üzerine yaptığı çalışmasında, piyasada rekabet güçlendikçe firma yöneticilerinin baskı altında kalarak kaynakları etkin şekilde kullandıklarını ve bu durumun toplam faktör verimliliğini arttığını göstermişledir. Yazarların ortaya koyduğu sonuç ile bu çalışmada eşik değerin üzerinde rekabet artışının toplam faktör verimliliği üzerinde ortaya çıkardığı pozitif etki benzerlik göstermektedir. Bununla birlikte, literatürde yer alan diğer bir grup çalışma rekabet ve toplam faktör verimliliği arasındaki doğrusal olmayan ilişkinin analizine odaklanmaktadır. Farklı teknikler kullanılarak yapılan çalışmaların sonuçlarında genel olarak, rekabet ve toplam faktör verimliliği arasında ters-U şeklinde bir ilişki ortaya konulmaktadır (Aghion vd., 2005; Van Reenen, 2011; Marshall ve Parra 2019). Doğrusal olmayan ters-U şeklindeki ilişki, belli bir dönün noktasının (eşik değer) ötesine geçildiğinde piyasa yoğunlaşmasının giderek artması ve bunun sonucunda rekabetin ortadan kalkarak TFP büyümesinin azalması anlamına gelmektedir (Polemis, 2020). Bu çalışmada, kullanılan rekabet göstergesi (Lerner) rekabet artışı şeklinde tanımlandığı için (1-Lerner), eşik değerin ötesine geçildiğinde yoğunlaşma azalmakta ve rekabet artmaktadır (Şayet, orijinal Lerner indeksi değerleri kullanılsaydı, eşik değerin üzeri rekabet azalışını gösterecekti). Dolayısıyla, yapılan tanımlamadan kaynaklanan yorum farklılı̆ı görülmekle birlikte, bu çalışmada da ulaşılan bulgular literatürle aynı yöndedir (Chen, Polemis ve Stengos, 2018).

Tahmin sonuçlarına göre eşik değer üzerindeki rekabet artışı toplam faktör verimliliğinin artış hızını 0,017 oranında artırmaktadır. Bu sonuç, rekabetle birlikte ortaya çıkan tahsis ekinliğinin pozitif etkisini göstermektedir. Öte yandan, ikinci rejimde bulunan kalıclık parametresi (initialTFP $\left.P_{i t}\right)$ değeri $(0,020)$ pozitif ve istatistiksel olarak anlamlı bulunmuştur. Genel olarak, rekabetçi ortamda bir dönem önce gerçekleşen toplan faktör verimliliği, bir dönem sonra gerçekleşen toplam faktör verimliliği üzerinde pozitif etkide bulunmaktadır. Bu sonuç değerlendirildiğinde, rekabetçi ortamda yer alan bir firmanın toplam faktör verimliliğinin toplam faktör verimliliğine katkısı yüksektir. Ölçek büyüklüğü parametresinin $\left(S i z e_{i t}\right)$ negatif olması, rekabetçi bir ortamda, ölçek artışının etkisinin negatif olduğunu göstermektedir. Bunun anlamı, ele alınan dönemde örneklem içinde yer alan firmaların optimal ölçek büyüklüğüne sahip olmadıklarıdır. Bununla birlikte, rekabetçi ortamda maliyet $\left(\right.$ Cost $\left._{i t}\right)$ artışının toplam faktör verimliliğinde büyümesi üzerinde negatif etkisinin olması, maliyet kontrolünde etkin olunmadığı yönünde bir bulgu olarak değerlendirilmektedir. Sermaye yoğunluğunun ( Cap_int $_{i t}$ ) rekabetçi ortamda toplam faktör büyümesini artıran en önemli değişken olduğu sonucu rekabetçi ortamda, sermaye yoğun üretimin belirlediğini göstermektedir. Elde edilen bulgularda ulaşılan önemli bir sonuç da yeni firmaların rekabet ortamında toplam faktör verimliliğindeki artışı hızlandırmasıdır.

Belirtilen bulgulara bağlı olarak, özellikle sermaye yoğun ve yeni kurulan sektörlerde rekabeti artıracak uygulamaların tahsis etkinliği ile birlikte toplam faktör verimliliği büyümesini hızlandırması 
beklenmektedir. Buna yönelik olarak üretim sürecindeki vergiler ile kurumlar vergisi gibi uygulamaların bir politika aracı olarak kullanılması mümkündür.

Bu çalışmanın analiz kısmı imalat sanayi firmaları ile sınırlıdır. Veri setinde yer alan firmalar kamuya açık ve genellikle daha büyük ölçekli firmalardan oluşmaktadır. Bununla birlikte, orta ve küçük ölçekli firmaları da içeren daha büyük veri setleri ile yapılacak çalışmalar karşılaştırılabilir ve istikrarlı sonuçlar açısından önemlidir. Çalışmanın sınırları içinde firma bazlı rekabet analizi yapılmakta ve rekabetin toplam faktör verimliliği üzerindeki etkisi analiz edilmektedir. Ancak, rekabet gücünün temel bileşenlerinden birisi etkinliktir. Bundan sonra yapılacak çalışmalarda, firmaların etkinlik düzeyleri hesaplanabilir ve firma etkinliğinin rekabet kanalından toplam faktör verimliliği üzerindeki etkisi analiz edilebilir. Çalışmada toplam faktör verimliliğinin tüm potansiyel belirleyenleri kontrol edilmemektedir. Yapılacak çalışmalarda toplam faktör verimliliği üzerinde etkili olabilecek firma ve sektöre özgü alternatif kontrol değişkenleri kullanılabilir.

\section{Beyan ve Açıklamalar (Declarations and Disclosures)}

Yazarların Etik Sorumlulukları (Ethical Responsibilities of Authors): Bu çalışmanın yazarı, araştırma ve yayın etiği ilkelerine uyduğunu kabul etmektedir.

Çıkar Çatışması (Conflicts of Interest): Yazar tarafından herhangi bir çıkar çatışması beyan edilmemiştir.

Finansal Destek (Funding): Yazar, çalışmanın hazırlanması ve/veya yayınlanması sürecinde herhangi bir finansal destek almamıştır.

Yazar Katkı Oranı (Author Contributions): Yazar; kavramlaştırma ve çalışma dizaynı, verilerin toplanması, verilerin analizi ve sonuçların yorumlanması, çalışmanın ilk/taslak halinin yazılması, çalışmanın gözden geçirilmesi ve düzenlenmesi/düzeltilmesi aşamalarından tek başına sorumlu olduğunu beyan etmektedir.

Intihal Denetimi (Plagiarism Checking): Bu çalışma, intihal tarama programı kullanılarak intihal taramasından geçirilmiştir.

\section{Son Notlar}

1. TÜiK (2020) tarafından yayımlanan raporda, "250 kişiden az yıllık çalışan istihdam eden ve yıllık net satış hasılatı veya mali bilançosundan herhangi biri 125 milyon Türk Lirasını aşmayan girişimler Küçük ve Orta Büyüklükteki Işsletmeler (KOBi) olarak tanımlanmaktadır." Bu kapsamda, çalışmada yer alan 77 firmadan 18 tanesi Küçük ve Orta Ölçekli, 59 tanesi Büyük Ölçekli firma tanımına girmektedir.

\section{Kaynaklar}

Aghion, P., \& Howitt, P. (1992). A model of growth through creative destruction. Econometrica, 60(2), 323-351.

Aghion, P., Bloom, N., Blundell, R., Griffith, R., \& Howitt, P. (2005). Competition and innovation: An inverted-U relationship. The Quarterly Journal of Economics, 120(2), 701-728.

Aghion, P., \& Schankerman, M. (2004). On the welfare effects and political economy of competition enhancing policies. The Economic Journal, 115(498), 800-824.

Aghion, P. (2017). Entrepreneurship and growth: Lessons from an intellectual journey. Small Business Economics, 48(1), 9-24.

Amable, B., Ledezma, I., \& Robin, S. (2016). Product market regulation, innovation, and productivity. Research Policy, 45(10), 2087-2104.

Arai, K. (2005). Competition and sector growth. Journal of Social Science, Institute of Social Science, University of Tokyo, 56(3), 53-87.

Arellano, M., \& Bond, S. (1991). Some tests of specification for panel data: monte carlo evidence and an application to employment equations. The Review of Economic Studies, 58(2), 277-297.

Arrow, K. (1962). The Economic implications of learning by doing. Review of Economic Studies, 29(80), 155-173. 
Baily, M. N., \& Solow, R. M. (2001). International productivity comparisons built from the firm level. Journal of Economic Perspectives, 15(3), 151-172.

Baumann, J., \& Kritikos, A. S. (2016). The link between R\&D, innovation and productivity: Are micro firms different? Research Policy, 45(6), 1263-1274.

Blundell, R., Griffith, R., \& Reenen, J. V. (1999). Market share, market value and innovation in a panel of British manufacturing firms. Review of Economic Studies, 66(1), 529-554.

Bloom, N., \& Van Reenen, J. (2010). Why do management practices differ across firms and countries? Journal of Economic Perspectives, 24(1), 203-224.

Caner, M., \& Hansen, B. E. (2004). Instrumental variable estimation of a threshold model. Econometric Theory, 20(5), 813-843.

Carlin, W., Schaffer, M., \& Seabright, P. (2004). A minimum of rivalry: Evidence from transition economies on the importance of competition for innovation and growth. Journal of Economic Analysis and Policy: Contributions, 3(1), 1-43.

Caloghirou, Y., Protogerou, A., Spanos, Y., \& Papagiannakis, L., (2004). Industry- versus firm-specific effects on performance: Contrasting SMEs and large-sized firms. European Management Journal, 22(2), 231-243.

Chen, C., Polemis, M., \& Stengos, T. (2018). On the examination of non-linear relationship between market structure and performance in the US manufacturing industry. Economics Letters, 164, 1-4.

Correa, J. A. (2012). Competition and innovation: An unstable relationship. Journal of Applied Econometrics, 27(1), 160166.

Correa, J. A., \& Ornaghi, C. (2014). Competition and innovation: Evidence from US patent and productivity data. The Journal of Industrial Economics, 62(2), 258-285.

Dasgupta, P., \& Stiglitz, J. E. (1980). Industrial structure and the nature of innovative activity. Economic Journal, 90(1), 266-293.

Diewert, W. E., Caves, D. W., \& Christensen, L. R. (1982). The Economic theory of index numbers and the measurement of input, output, and productivity. Econometrica, 50(6), 1393-1414.

Farrell, M. J. (1957). The measurement of productive efficiency. Journal of the Royal Statistical Society, General Series A, 120(3), 253-281.

Flath, D. (2011). Industrial concentration, price-cost margins, and innovation. Japan and the World Economy, 23(2), 129139.

Geroski, P. A. (1990). Innovation, technological opportunity, and market structure. Oxford Economic Papers, 42(3), 586602.

Gilbert, R. J., \& Newbery, D. M. G. (1982). Preempting patenting and the persistence of monopoly. American Economic Review, 72(3), 514-526.

Hansen, B. E. (1999). Threshold effects in non-dynamic panels: Estimation, testing, and inference. Journal of Econometrics, 93(1), 345-368.

Hart, O. (1983). The market mechanism as an incentive scheme. Bell Journal of Economics, 14(2), 366-382.

Hashmi, A. R. (2013). Competition and innovation: The inverted-U relationship revisited. The Review of Economics and Statistics, 95(5), 1653-1668.

Hashmi, A. R., \& Biesebroeck, J. V. (2016). The relationship between market structure and innovation in industry equilibrium: A case study of the global automobile industry. Review of Economics and Statistics, 98(1), 192-208.

Haskel, J. (1991). Imperfect competition, work practices and productivity growth. Oxford Bulletin of Economics \& Statistics, 53(3), 265-279.

Hicks, J. R. (1935). Annual survey of economic theory: The theory of monopoly. Econometrica, 3, 1-20.

Inui, T., Kawakami, A., \& Miyagawa, T. (2012). Market competition, differences in technology, and productivity improvement: An empirical analysis based on Japanese manufacturing firm data. Japan and the World Economy, 24(3), 197-206.

Jorgenson, D. W. (1995). Productivity. Cambridge, MA: Harvard University Press.

Kancs, A., \& Siliverstovs, B. (2016). R\&D and non-linear productivity growth. Research Policy, 45(1), 634-646.

Kato, A. (2009). Product market competition and productivity in the Indian manufacturing industry. The Journal of Development Studies, 45(10), 1579-1593. 
Kumbhakar, S. C., Baardsen, S., \& Lien, G. (2012). A new method for estimating market power with an application to Norwegian sawmilling. Review of Industrial Organization, 40(2), 109-129.

Kurul, Z. (2021). Avrupa Birliği'nde hanehalkı borcunun ekonomik büyüme üzerindeki etkisi: Hanehalkı borcu ne zaman "çok fazla"? Business and Economics Research Journal, 12(2), 269-285.

Lanau, S., \& Topalova, P. (2016). The impact of product market reforms on firms productivity in Italy. IMF Working Paper, No. 16/119.

Lerner, A. (1934). The concept of monopoly and the measurement of monopoly power. The Review of Economic Studies, 1(3), 157-175.

Marshall, G., \& Parra, A. (2019). Innovation and competition: The role of the product market. International Journal of Industrial Organization, 65, 221-247.

Mukoyama, T. (2003). Innovation, imitation, and growth with cumulative technology. Journal of Monetary Economics, $50(2), 361-380$

Nickell, S. (1981). Biases in dynamic models with fixed effects. Econometrica: Journal of the Econometric Society, 49(6), 1417-1426.

Nickell, S. J. (1996). Competition and corporate performance. Journal of Political Economy, 104(4), 724-746.

OECD, (1993). Glossary of industrial organization economics and competition law. OECD Publishing.

Okada, Y. (2005). Competition and productivity in Japanese manufacturing industries. Journal of the Japanese and International Economics, 19(4), 586-616.

Pant, M., \& Pattanayak, M. (2010). Corporate governance, competition and firm performance: Evidence from India. Journal of Emerging Market Finance, 9(3), 347-381.

Polemis, M. L. (2020). A note on the estimation of competition-productivity nexus: A panel quantile approach. Journal of Industrial and Business Economics, 47(1), 663-676.

Poschke, M. (2009). The regulation of entry and aggregate productivity. EUI Working Paper.

Raymond, W., Mairesse, J., Mohnen, P., \& Palm, F. (2015). Dynamic models of R\&D, innovation and productivity: Panel data evidence for Dutch and French manufacturing. European Economic Review, 78(1), 285-306.

Romer, P. (1986). Increasing returns and long-run growth. Journal of Political Economy, 94(5), 1002-1037.

Seo, M. H., \& Shin, Y. (2016). Dynamic panels with threshold effect and endogeneity. Journal of Econometrics, 195(2), 169-186.

Satpathy, L. D., \& Mishra, B. R. (2019). Size-competition-productivity nexus: Evidence from Indian manufacturing firms. South Asia Economic Journal, 20(2), 303-321.

Scharfstein, D. (1988). Product market competition and managerial slack. Rand Journal of Economics, 19(1), 147-155.

Scherer, F. M., \& Ross, D. (1990). Industrial market structure and economic performance. Boston, MA: Houghton Mifflin.

Schiffbauer, M., \& Ospina, S. (2010). Competition and firm productivity; Evidence from firm-level data. IMF Working Papers.

Schmidt, K. M. (1997). Managerial incentives and product market competition. Rand Journal of Economics, 64(2), 191213.

Schmitz, J. A. (2005). What determines productivity? Lessons from the dramatic recovery of the U.S. and Canadian iron ore industries following their early 1980s crisis. Journal of Political Economy, 113(3), 582-625.

Schumpeter, J. A. (1942). Capitalism, socialism, and democracy. New York, NY: Harper.

Schumpeter, J. A. (1943). Capitalism, socialism and democracy. London: Allen Urwin.

Solow, R. (1956). A contribution to the theory of economic growth. Quarterly Journal of Economics, 70(1), 65-94.

Van Reenen, J. (2011). Does competition raise productivity through improving management quality? International Journal of Industrial Organization, 29(3), 306-316. 
This Page Intentionally Left Blank 